\title{
Wheat Production in Uttar Pradesh - A Study on the Growth and Instability Over Time
}

\author{
Anwesha Dey*, M. Anoop and Yash Gautam \\ ${ }^{1}$ Department of Agricultural Economics, Institute of Agricultural Sciences, Banaras Hindu \\ University, Varanasi, India \\ *Corresponding author
}

A B S T R A C T

K e y w o r d s
Wheat, Uttar
Pradesh, CAGR,
Instability,
Decomposition
Article Info
$\begin{aligned} & \text { Accepted: } \\ & \text { 05 February } 2020 \\ & \text { Available Online: } \\ & 10 \text { March } 2020\end{aligned}$

\section{Introduction}

Wheat is an important cereal preferred across the globe and is the dominant staple food in many countries. It is one of the first domesticated crops and has been one of the staples in the diet of many civilizations for more than 8,000 years. The adaptability of wheat crop for cultivation in various climatic regions, the ease of storage and the ability to
Wheat is an important staple food crop throughout the globe. India is the second largest producer of wheat after China. Being an agrarian state leading in area and production of wheat in India, Uttar Pradesh holds a prominent place in wheat production. The present study examines the growth and instability in wheat area, production and productivity in Uttar Pradesh state over a period of 1950-51 to 2015-16 and also the study tries to decompose the major factors contributing to growth of wheat production in the state. The analysis revealed that throughout the whole period, there is positive significant growth rate in area, production and yield. Sub-period wise analysis showed variations in the rate of growth through different time periods. The analysis of instability showed that production instability (73.7 per cent) was higher compared to area (32 per cent) and yield instability (43 per cent) throughout the whole period. Highest instability was found for the second sub-period, compared to other sub-periods. Decomposition analysis showed that interaction effect of area and yield was the major contributor to the growth in wheat production in the state. 
of global wheat production (101.29 million tonnes) and is the second largest producer of wheat after China. Demand of India's wheat in the world shows a rising trend. The country has exported 2,26,225.00 MT of wheat to the world for the worth of Rs. 424.94 crores / 60.55 USD Millions during the year of 201819 (Sendhil et al., 2019; www.apeda.gov.in). Uttar Pradesh is the largest wheat producing state in India, followed by Punjab, Haryana and Madhya Pradesh. More than 30 percent of area and production of wheat in India is by Uttar Pradesh state alone. Though Uttar Pradesh is leading in area and production of wheat, it's productivity is not the highest, and is less than the national average (Balaganesh et al., 2019). Being the highest producer of wheat in the country, growth and stability of wheat production in Uttar Pradesh has higher significance. Also, since agriculture is the main source of livelihood to majority of population in Uttar Pradesh where wheat accounts for highest share in gross cropped area, understanding the growth and instability scenario of wheat and the driving forces behind it in the state is of utmost importance.

Along with analysis of the total study period, it is imperative to have a look at each subperiod separately so that it will be helpful to identify in which sub-period there is a lag and which sub-period was the most progressive. This will be helpful for further analysis on the reasons behind this lag/ progress in a particular sub-period. Proper understanding of growth and instability scenario of an important crop like wheat is thus much relevant owing to its importance as a major food crop and also as a major part of the agricultural economy. By keeping these in mind the present study makes an attempt to analyze the growth and instability in wheat area, production and productivity over time and the relative contribution of area, yield and interaction effects in the growth of wheat in Uttar Pradesh., the major wheat producing state in India.

\section{Materials and Methods}

The study was based on secondary data collected from Indiastat website. Data on area, production and yield of wheat in Uttar Pradesh for the period of 1950-51 to 2015-16 was used for the analysis. The entire study period was further divided into seven subperiods as: Period I (1950-51 to 1959-60), Period II: (1960-61 to 1969-70), Period III: (1970-71 to 1979-80), Period IV: (1980-81 to 1989-90), Period V: (1990-91 to 1999-00), Period VI: (2000-01 to 2009-10) and Period VII: (2010-11 to 2015-16).

\section{Compound annual growth rate}

Compound annual growth rate (CAGR) was estimated using the following functional form:

$\ln \mathrm{Y}=\mathrm{a}+\mathrm{bt}$

Where, $\mathrm{Y}$ is the time series data of area, production or yield of wheat - for which growth rate is calculated, ' $t$ ' is the trend term and ' $a$ ' is the constant coefficient. The slope coefficient ' $b$ ' measures the relative change in $\mathrm{Y}$ for a given absolute change in the value of explanatory variable ' $t$ '. Compound annual growth rate can be calculated from the value obtained for ' $b$ ' as:

$\mathrm{CAGR}=[\operatorname{antilog} \mathrm{b}-1] \times 100$

The values of compound growth rates obtained were also tested for their significance using student ' $t$ ' test.

\section{Co-efficient of Variation}

Instability is the deviation from the trend. It can be measured by using the coefficient of variation. The standard deviation as a percentage of means is called as the coefficient of variation. 
$\mathrm{CV}=(\mathrm{SD} / \mathrm{MEAN}) \times 100$

Where CV is the Co-efficient of variation, SD is the standard deviation of the variable.

\section{Decomposition analysis}

Decomposition helps us to get to know about the constituent elements of a particular parameter. To estimate the contribution of area, productivity and interaction of the two in total production, following model was used. A number of studies have applied same model to analyze similar objectives (Bastine and Palanisami, 1994; Kakali and Basu, 2006; Sharma et al., 2017).

$\Delta \mathrm{P}=\mathrm{A}_{0} \Delta \mathrm{Y}+\mathrm{Y}_{0} \Delta \mathrm{A}+\Delta \mathrm{A} \Delta \mathrm{Y}$

Change in production $=$ Yield effect + Area effect + Interaction effect

Where, $\Delta \mathrm{P}$ is change in production, $\mathrm{A}_{0}$ is area in the base year, $\Delta \mathrm{A}$ is change in the area and $\Delta \mathrm{Y}$ is the change in yield. $\Delta \mathrm{A} \Delta \mathrm{Y}$ corresponds to the interaction effect.

\section{Results and Discussion}

Growth in wheat area, production and productivity

Total area under wheat in Uttar Pradesh increased from 3316 thousand hectares to 9645 thousand hectares during 1950-51 to 2015-16. The growth trend shows an overall significant annual growth rate of 1.63 per cent. The sub-period wise compound growth trend analysis for the area under wheat shows a declining trend in the compound growth rate except in the second sub-period.

In 1950-51 wheat production in Uttar Pradesh was 2721 thousand tonnes which approximately increased to ten folds to 27518 thousand tonnes in 2015-16. The wheat production has recorded a significant growth rate of 3.44 per cent from 1950 to 2016 . The sub-period wise growth trend analysis suggests that it was positive growth rate in all sub periods except in the last sub-period of 2010- 2016, which shows a negative growth rate. The second, third, fourth and fifth subperiods show a significant growth rate.

Per hectare yield of wheat in the state increased from $820 \mathrm{~kg} /$ ha to $2636 \mathrm{~kg} / \mathrm{ha}$ during 1950-51 to 2015-16. The growth trend analysis for wheat suggests that the yield was growing at a compound annual growth rate of 1.75 per cent from $1950-51$ to $2015-16$. In the sub-period wise analysis, yield shows a positive growth rate except in the last subperiod where it shows a negative growth rate of -2.734 per cent. There has been significant growth in the sub-periods of 1980-90 and 1990-00. The highest growth rate observed during the study was in the sub-period 198081 to $1989-90$.

\section{Instability in wheat area, production and productivity}

Details of instability in wheat area, production and yield in Uttar Pradesh for the overall period (1950-51 to 2015-16) and sub-periods is presented in Table 2. During the entire period, highest variation was noticed for production in comparison to area and yield. The variation in production was 73.7 per cent, while the variation in area and yield were 32 per cent and 43 per cent respectively. During the sub-period analysis, highest instability was noticed during the second sub-period, it was 13 per cent variation in area, 27 per cent and 16.2 per cent variation in production and yield respectively. The stability in the area under wheat cultivation implies that wheat crop holds a significant portion in cropping pattern of the state.

The instability in production and productivity was found to be high in sub-period II. The reasons for instability during period II might 
be the launch of the program Green cropping pattern in the state. revolution, which brought changes in the

Table.1 Compound Annual Growth Rates of Area, Production and Yield of Wheat in Uttar Pradesh

\begin{tabular}{|c|c|c|c|c|c|c|c|c|}
\hline \multirow[b]{2}{*}{ Particulars } & \multicolumn{7}{|c|}{ Periods } & \multirow{2}{*}{$\begin{array}{l}\text { Overall } \\
\text { Period }\end{array}$} \\
\hline & I & II & III & IV & $\mathbf{V}$ & VI & VII & \\
\hline Area & $\begin{array}{l}1.57^{* *} \\
(3316)\end{array}$ & $\begin{array}{l}3.16^{* *} \\
(3939)\end{array}$ & $\begin{array}{l}2.46^{* * *} \\
(5907)\end{array}$ & $\begin{array}{l}0.63^{*} \\
(8112)\end{array}$ & $\begin{array}{l}0.93^{* *} \\
(8568)\end{array}$ & $\begin{array}{l}0.45 \\
(9239)\end{array}$ & $\begin{array}{l}0.01 \\
(9637)\end{array}$ & $1.63^{* *}$ \\
\hline Production & $\begin{array}{l}1.79 \\
(2721)\end{array}$ & $\begin{array}{l}4.82^{* *} \\
(3945)\end{array}$ & $\begin{array}{l}2.55^{\text {*** }} \\
(7690)\end{array}$ & $\begin{array}{l}3.35^{* *} \\
(13385)\end{array}$ & $\begin{array}{l}2.53^{* *} \\
(20229)\end{array}$ & $\begin{array}{l}0.89 \\
(25168)\end{array}$ & $\begin{array}{l}-2.72 \\
(30001)\end{array}$ & $3.44^{* *}$ \\
\hline Yield & $\begin{array}{l}0.36 \\
(820)\end{array}$ & $\begin{array}{l}1.61 \\
(1001)\end{array}$ & $\begin{array}{l}0.09 \\
(1302)\end{array}$ & $\begin{array}{l}2.78^{* *} \\
(1650)\end{array}$ & $\begin{array}{l}1.66^{* *} \\
(2344)\end{array}$ & $\begin{array}{l}0.44 \\
(2724)\end{array}$ & $\begin{array}{l}-2.73 \\
(3113)\end{array}$ & $1.79^{* *}$ \\
\hline
\end{tabular}

Table.2 Instability in Area, Production and Yield of Wheat in Uttar Pradesh

\begin{tabular}{|c|c|c|c|c|c|c|c|c|c|}
\hline \multirow{2}{*}{\multicolumn{2}{|c|}{ Particulars }} & \multicolumn{7}{|c|}{ Periods } & \multirow{2}{*}{$\begin{array}{l}\text { Overall } \\
\text { Period }\end{array}$} \\
\hline & & I & II & III & IV & $\mathbf{V}$ & VI & VII & \\
\hline \multirow[t]{3}{*}{ Area } & SD & 270.74 & 569.76 & 580.27 & 266.97 & 262.90 & 202.41 & 90.31 & 2281.71 \\
\hline & Mean & 3711.4 & 4405.6 & 6485.7 & 8346.3 & 8994.09 & 9239.6 & 9738.66 & 7125.14 \\
\hline & $\mathrm{CV}(\%)$ & 7.29 & 12.93 & 8.95 & 3.20 & 2.92 & 2.19 & 0.93 & 32.02 \\
\hline \multirow[t]{3}{*}{ Production } & SD & 254.17 & 1230.3 & 1630.8 & 1766.8 & 1978.25 & 1335.9 & 3343.85 & 9656.01 \\
\hline & Mean & 2999.6 & 4437.1 & 8453.9 & 15873 & 22181.6 & 15688.9 & 28054.3 & 13101.02 \\
\hline & $\mathrm{CV}(\%)$ & 8.47 & 27.73 & 19.29 & 11.13 & 8.92 & 8.515 & 11.92 & 73.70 \\
\hline \multirow[t]{3}{*}{ Yield } & SD & 47.33 & 161.10 & 156.68 & 166.63 & 166.05 & 141.30 & 349.56 & 793.02 \\
\hline & Mean & 810.9 & 992.6 & 1298.3 & 1896.1 & 2461.8 & 2738.4 & 2881.66 & 1807.14 \\
\hline & $\mathrm{CV}(\%)$ & 5.84 & 16.23 & 12.07 & 8.79 & 6.75 & 5.16 & 12.13 & 43.88 \\
\hline
\end{tabular}

Table.3 Area, yield and interaction effect on the production of wheat in Uttar Pradesh

\begin{tabular}{|c|c|c|c|c|c|c|c|c|}
\hline \multirow[t]{2}{*}{ Particulars } & \multicolumn{7}{|c|}{ Periods } & \multirow[t]{2}{*}{$\begin{array}{l}\text { Overall } \\
\text { Period }\end{array}$} \\
\hline & I & II & III & IV & $\mathbf{V}$ & VI & VII & \\
\hline Area effect & 121.96 & 47.39 & 54.82 & 21.99 & 33.64 & 25.47 & -5.52 & 22.50 \\
\hline Yield effect & -19.21 & 40.77 & 37.69 & 73.46 & 62.17 & 72.66 & 104.70 & 26.56 \\
\hline $\begin{array}{l}\text { Interaction } \\
\text { effect }\end{array}$ & -2.75 & 11.84 & 7.49 & 4.56 & 4.20 & 1.86 & 0.82 & 50.94 \\
\hline
\end{tabular}


Relative contribution of area and yield in the growth of wheat in Uttar Pradesh

Decomposition is done to find out the area, yield and interaction effect on growth of wheat production in Uttar Pradesh for the overall period (1950-51 to 2015-16), and then in each sub-period separately. Results are presented in Table 3. The analysis of the overall period shows that the area and yield effects were 22.5 per cent, 26.5 per cent respectively and interaction effect was 50.94 per cent. This states that area and yield together contributed towards growth of wheat production in the state.

The sub-period wise analysis suggests that area had a positive effect of 121.96 per cent whereas yield had a negative effect on wheat production during the first sub-period. During the second sub-period of the study, area, yield and interaction effects were 47.39 per cent, 40.77 per cent and 11.84 per cent. During third, fourth, fifth and sixth sub-periods, positive influence of area and yield on wheat production was observed. In seventh subperiod negative area effect on production was noticed.

From the analysis of growth and instability in wheat area, it was concluded that area was increasing at an annual growth rate of 1.69 per cent throughout the whole study period; but the sub-period wise analysis showed a declining trend in growth over the time. Productivity was found to have an annual growth rate of 1.7 per cent in the whole study period. Both production and productivity showed positive growth rate throughout the sub-periods. While looked at the instability, Production instability (73.7 per cent) was found higher compared to area (32 per cent) and yield instability (43 per cent) throughout the whole period. When took each sub-period separately, highest instability was found for the second sub-period. Using decomposition analysis, it was revealed that interaction effect played a crucial role in the growth of wheat production in the state during the study period.

\section{References}

Balaganesh, G., Makarabbi, G., and Sendhil, R. (2019). Tracking the performance of wheat production in Uttar Pradesh. Indian Journal of Economics and Development, 15(2): 216-224. DOI:10.5958/2322-0430.2019.00026.X

Basitine, C.L., and Palanisami, K.P. (1994). An analysis of growth trends in principal crops in Kerala. Agricultural Situation in India, 48(12): 885-891.

Janakiraman, A. (2020, January 16). Agriculture and crops: A focus on wheat cultivation, https://www.openaccessgovernment.org /agriculture-and-crops-a-focus-onwheat-cultivation/80915/

Kakali, M., and Basu, P. (2006). Measurement of growth trend: An econometric study of food grains production in west. Bengladesh Journal of Agricultural Econonomics, 3(3): 4455.

Sendhil, R., Kumar, A., Singh, S., and Singh, G.P. (2019). Wheat production technologies and food security: The nexus and prospects, In A. Pouchepparadjou, L. Umamaheswari, and D. Sivasakthi (Eds.), Ascertaining Food Security through Livelihood Enriching Interventions: Challenges and Opportunities (7-15).

Sharma, H., Parihar, T.B., and Kapadia, K. (2017). Growth rates and decomposition analysis of onion production in Rajasthan State of India. Economic Affairs, 62(1): 157-161. DOI: 10.5958/2230-7311.2017.00051.4

http://apeda.gov.in/apedawebsite/SubHead_Pr oducts/Wheat.htm 


\section{How to cite this article:}

Anwesha Dey, M. Anoop and Yash Gautam. 2020. Wheat Production in Uttar Pradesh - A Study on the Growth and Instability over Time. Int.J.Curr.Microbiol.App.Sci. 9(03): 550-555. doi: https://doi.org/10.20546/ijcmas.2020.903.064 